\title{
Simulation model for the structure of Finnish agriculture
}

\author{
SEPPO HASSINEN and LAURI KETTUNEN \\ Agricultural Economics Research Institute, Rukkila, 00001 Helsinki 100, Finland
}

Abstract. The simulation model for the structure of agriculture makes up one part of the Finnish food model. The structure of agriculture is described in the model by the agricultural population as well as by the number, the average size and distribution of all the farms, dairy farms, pig farms, poultry farms and non-animal farms.

The agricultural population is calculated by forecasting its share from the total population as a function of GDP. The number of farms is derived from the agricultural population by assuming that the size of a farm family is constant. The average size of the farm is derived by dividing the total acreage by the number of farms. The distribution of farms is forecasted by applying a logarithmic normal distribution function.

The starting points for the structure of animal production are the consumption forecasts and self-sufficiency targets. The development of the average yield per animal is forecasted by applying a trend line. Also the average size of animal farms is forecasted by a trend. The number of animal farms is obtained simply by dividing the number of animals by the average farm size.

\section{Introduction}

The structure of Finnish agriculture has changed rapidly. The acreage of farms has decreased about 10 per cent in the 70's and the cultivated area has decreased even more due to soil bank, fallowing and afforestation policy actions. At the same time, the farm population has fallen considerably and with it the number of farms. Agricultural production has, however, not decreased in the same ratio; on the contrary it can be said that production has remained stable or has risen slightly.

Animal production represents the major part of agricultural production with the most important still being milk production, the share of which is nearly half of agriculture's annual gross return. Considerable changes have occurred in milk production, falling in the 70's, but now it is remaining at the present level and may raise slightly in the future. An essential feature is, however, the rapid decrease of the number of dairy cows which is being compensated by the growth af average milk yield, so that production is about constant. Horses have fallen in number to little above zero but the numbers of pigs and hens have grown strongly.

The distribution of farms has changed considerably. The acreage per farm has not increased very much but small farms are dropping out of production and thus the large farms' share is increasing. Attempts have been made to control this distribution to some extent by making the establishment of large production units possible only if permission is granted. 
The ongoing structural development of agriculture is not wholly accepted, since it means a decrease in farm population with rural areas becoming de-populated. There are, however, strong internal factors in the development which are difficult to overcome if this structural change is to be affected. Therefore it is interesting to study how development will continue without strong policy measures. The purpose of this study is to construct a mathematical model which can be used to follow the change of the structure of agriculture. The model is a part of a simulation model for the whole agriculture which is briefly described below.

\section{Food and agriculture model for Finland}

The purpose of the Finnish food model is to describe the interrelationships of the various parts of agriculture and serve as a policy tool for decision-makers in long term policy assessment and planning. It is not intended primarily for prognostication but rather for simulation of different development paths when different policy targets are set or different policy actions are taken.

The model is a recursive planning model, beginning from population and continuing to a structural model. Consumption is the major determinant in the model. It is a function of income and prices and together with self-sufficiency rates it determines agricultural production. This, in turn, effects the structure of agriculture as is explained later in this paper.

The yield level of crops is determined by the optimum use of fertilizers as the prices of fertilizers and products are given. The later ones are scenario variables whose evolution can be freely regulated. When production targets are set by the model the land needed can be calculated as the ratio of production and yield level.

Different versions of the model have been built, for example, the growth of Gross Domestic Product (GDP) has been considered in the present version as a scenario variable whose growth rate can be varied easily. Therefore, the GDP has been allowed to increase by a fixed percentage from year to year. In another version the non-agricultural production is a function of capital and labor force (see KETTUNEN 1980 ). Since the growth of the economy is considered by the authors to be very uncertain the model of GDP is of minor importance to the functioning of the structural model.

\section{Structural model for agriculture}

\subsection{Social structure of agriculture}

The social structure of agriculture is described in the model by the agricultural population as well as the number of farms, the average farm size and distribution. So far the agricultural population is calculated by forecasting its share from the total population as a function of GDP. The total population is assumed to grow by a fixed percentage (in this case 0.2 per cent) per year. The share of the agricultural population $(\mathrm{AW}(\%))$ is estimated as follows:

$$
\mathrm{AW}(\%)_{\mathrm{t}}=0.03+0.87 \mathrm{e}^{-1.332 \mathrm{GDP}} \mathrm{t}
$$


It is presumed here that the minimum share would be 3 per cent but this minimum limit can be, however, easily adjusted within the model. The agricultural population (AW) is obtained by multiplying the total population by the percentage share:

$$
A W_{t}=A W(\%)_{t} \times W_{t}
$$

The number of farms is derived from the agricultural population by assuming that the size of farm family is constant ( 2.5 persons per family) and the number of farms (FARMS) is assumed to be the same as the number of farm families (households):

$$
\text { FARMS }_{\mathrm{t}}=\mathrm{AW}_{\mathrm{t}} / 2.5
$$

The average size of the farm (ASF) is derived by dividing the total acreage (TAREA) by the number of farms:

$$
\text { ASF }_{\mathrm{t}}=\text { TAREA }_{\mathrm{t}} / \text { FARMS }_{\mathrm{t}}
$$

The net annual decrease of the total acreage is estimated to be 0.3 per cent.

The distribution of farms is forecasted by applying a logarithmic normal distribution function (see WALLENBECK 1979, p. 155-190). The farms are classified according to size using the following factors: total farms and farms without animals; hectares per farm, animal farms; animals per farm. Usually the distribution of farms is skew, i.e. there are more of smaller farms than large ones. If the size distribution is drawn on a logistic scale, a frequency curve is obtained which is close to a normal distribution. When the average size increases the frequency curve moves to the right on the logistic scale but often it keeps its normal form.

The fit of the logarithmic normal distribution to the distribution of the farm size was studied by HASSINEN (1980), and it was found that usually this assumption is valid in the Finnish case. In order to apply the log-normal distribution for the forecasts of the size distribution of farms, the distribution in the basic year and the function of the development of the average farm size must be known. Therefore the lognormal distribution can, in principle, easily be applied to the forecast of the size distribution.

The cumulative share of each size class of farm is obtained from the following:

$$
\begin{aligned}
\mathrm{F}\left(\mathrm{x}_{\mathrm{i}}\right)=\mathrm{Q}\left(\mathrm{S}^{-1}\left(\ln \mathrm{x}_{\mathrm{i}}-\left(\ln \overline{\mathrm{x}}-\mathrm{S}^{2} / 2\right)\right)\right) \text {, where } \\
\mathrm{F}\left(\mathrm{x}_{\mathrm{i}}\right)=\text { forecast of percentage share of farms smaller than } \mathrm{x}_{\mathrm{i}} \text { of all farms } \\
\mathrm{x}_{\mathrm{i}}=\text { size class limit for } \mathrm{i} \\
\mathrm{Q}=\text { standardized normal distribution } \\
\mathrm{S}^{2}=\text { variance } \\
\overline{\mathrm{x}}=\text { the average size of farms }
\end{aligned}
$$

The estimate of variance is estimated from

$$
\begin{aligned}
& \mathrm{S}^{2}=\left[\frac{\ln \mathrm{x}_{\mathrm{i}+\mathrm{n}}-\ln \mathrm{x}_{\mathrm{i}}}{\mathrm{Q}^{-1} \mathrm{Pn}_{\mathrm{i}+\mathrm{n}}-\mathrm{Q}^{-1}\left(\mathrm{Pn}_{\mathrm{i}}\right)}\right]^{2} \text {, where } \\
& \mathrm{Q}^{-1}=\text { inverse of normal distribution (normal distribution tables are read backwards) } \\
& \mathrm{Pn}_{\mathrm{i}}=\text { the cumulative percentage share of farms at the size class limit } \mathrm{i}
\end{aligned}
$$


Size class limits $\left(\mathrm{Pn}_{\mathrm{i}}\right.$ and $\left.\mathrm{Pn}_{\mathrm{i}}+\mathrm{n}\right)$ are selected so that their cumulative percentage shares are approximately symmetrical to the 50 per cent level, i.e. closer to the lower and upper quartile.

The growth of GDP, is assumed to be 2.5 per cent in the basic scenario. This growth rate produces a forecast according to which the share of agricultural population in 1990 would be 7.5 per cent, the number of farms 147900 and the average farm size 17.1 ha (Table 1). The changes in the distribution of farms is presented in Table 2 for the years 1975-1990.

\subsection{The structure of agricultural production}

Forecasting the structure of agricultural production is hampered by the lack of sufficient data regarding the level and development of specialization in different production lines. Therefore, methods applied for the forecasting of changes of production structure are usually simplified by assuming that specialization of the sector in question is fully realized. For example, every farm which has a single pig is counted into the pig farms irrespective of other possible production. This method obviosly results in a sum of all farm groups larger than the total number of farms. In this study farms are classified as dairy farms, pig farms, poultry farms and farms without animals.

Table 1. Agricultural population, number of farms, average farm size and total acreage in the period $1975-$ 1990.

\begin{tabular}{|c|c|c|c|c|c|}
\hline & $\begin{array}{c}\text { Total } \\
\text { acreage } \\
(1000 \mathrm{ha})\end{array}$ & $\begin{array}{c}\text { Number of } \\
\text { farms } \\
(1000)\end{array}$ & $\begin{array}{c}\text { Average } \\
\text { farm size } \\
\text { (ha) }\end{array}$ & $\begin{array}{c}\text { Agricultural } \\
\text { population } \\
(1000)\end{array}$ & $\begin{array}{c}\text { Agricultural } \\
\text { population } \\
\%\end{array}$ \\
\hline 1975 & 2641.0 & 273.0 & 9.7 & 671.6 & 14.3 \\
\hline 1978 & 2617.3 & 243.1 & 10.8 & 597.9 & 12.6 \\
\hline 1981 & 2593.8 & 215.5 & 12.0 & 530.0 & 11.1 \\
\hline 1984 & 2570.5 & 190.3 & 13.5 & 468.2 & 9.8 \\
\hline 1987 & 2547.5 & 167.8 & 15.2 & 412.8 & 8.6 \\
\hline 1990 & 2524.6 & 147.9 & 17.1 & 363.8 & 7.5 \\
\hline
\end{tabular}

Table 2. Actual and percentage farm size distribution in the period 1975-1990 (1000).

\begin{tabular}{|c|c|c|c|c|c|c|c|c|}
\hline & & & $\mathrm{ha} /$ & farm & & & & \\
\hline & $1-4.9$ & $5-9.9$ & $10-19.9$ & $20-29.9$ & $30-49.9$ & $50-99.9$ & $100-$ & Total \\
\hline 1975 & 96.1 & 88.3 & 61.7 & 16.6 & 8.0 & 2.1 & 0.2 & 273.0 \\
\hline & 35.2 & 32.3 & 22.6 & 6.1 & 2.9 & 0.8 & 0.1 & $100.0 \%$ \\
\hline 1978 & 74.3 & 78.3 & 60.7 & 17.8 & 9.2 & 2.6 & 0.2 & 243.1 \\
\hline & 30.5 & 32.2 & 25.0 & 7.3 & 3.8 & 1.1 & 0.1 & $100.0 \%$ \\
\hline 1981 & 56.1 & 68.0 & 58.6 & 18.8 & 10.4 & 3.3 & 0.3 & 215.5 \\
\hline & 26.1 & 31.6 & 27.2 & 8.7 & 4.8 & 1.5 & 0.1 & $100.0 \%$ \\
\hline 1984 & 41.3 & 57.9 & 55.5 & 19.6 & 11.6 & 4.0 & 0.4 & 190.3 \\
\hline & 21.7 & 30.4 & 29.2 & 10.3 & 6.1 & 2.1 & 0.2 & $100.0 \%$ \\
\hline 1987 & 29.9 & 48.1 & 51.6 & 20.0 & 12.8 & 4.8 & 0.6 & 167.8 \\
\hline & 17.8 & 28.7 & 30.7 & 11.9 & 7.6 & 2.9 & 0.4 & $100.0 \%$ \\
\hline 1990 & 21.3 & 39.3 & 47.0 & 20.0 & 13.8 & 5.7 & 0.8 & 147.9 \\
\hline & 14.4 & 26.6 & 31.8 & 13.5 & 9.3 & 3.9 & 0.5 & $100.0 \%$ \\
\hline
\end{tabular}


Since the supply of individual agricultural products is more flexible than the total supply of all agricultural products, it is obvious that changes in the production structure are also more flexible than the changes in the social structure of agriculture. Because of this flexibility, it is also possible to affect the structure by means of some specific agricultural policy. Therefore, making a long-term forecast of the structure of agricultural production without taking into account possible changes in consumption is unwise.

Experience has shown that the production of different agricultural products can be adjusted to some extent to the domestic consumption. Therefore, the starting point for the structure of animal production is the forecast of consumption of these products (ROUHIAINEN 1979). Production quantities are then derived by applying self-sufficiency targets and after production is determined, the number of animals can be derived. For that purpose, the forecast of the average yield per animal is made after which the number of animals is obtained by dividing production by the estimated average yield. In order to calculate the number of animal farms, the activities carried out on the average-sized farm should be specified and then the number of farms, which have animals, is simply obtained by dividing the number of animals by the average size of farms.

The development of the average size of animal farms is forecast simply by applying a trend line. Here, however, are the most serious weaknesses of the structural production model. It seems obvious that there is some kind of correlation between the volume of animal production and the average size of animal farms. For example, if milk production is limited it is necessary to reduce the number of dairy cows. It is likely that then propensity to stop milk production is the highest on the farms with a small number of dairy cows. Therefore in the production model it would be logical to expect a negative correlation between the number of cows and the average size of herds. On the other hand, if there is an oversupply of milk and the number of animals is reduced, there may be attempts to restrict the establishment of large production units or their expansion, slowing down the growth of average farm size. There appears to be some problems implicit in the calculation of this variable thus it is considered enough to use the linear trend method.

In the case of farms without animals, the model cannot be built from the production targets since a considerable part of crop production comes from farms which have also animal production. The calculation of the number of farms without animals is forecast therefore by applying a hyberbole function which is linked to the total number of farms.

\subsubsection{Structure of the dairy sector}

The starting point for the calculation of the volume of milk production is the consumption forecast of milk products. Production is estimated by setting a selfsufficiency target for milk after which production is obtained to the structure model from production model. To calculate the number of dairy cows corresponding to the production level required a model has been built which gives the milk yield per cow. The annual growth $(\triangle \mathrm{AY})$ of average yield is a scenario variable:

$$
\mathrm{AY}_{\mathrm{t}}=\mathrm{AY}_{1}+(\mathrm{t}-1) \triangle \mathrm{AY}, \quad \mathrm{t}=\text { time variable }
$$


The number of dairy cows $(\mathrm{NC})$ is obtained by dividing production $\left(\mathrm{Q}_{\mathrm{m}}\right)$ by the average yield:

(3.8) $\quad \mathrm{NC}_{\mathrm{t}}=\frac{\mathrm{Q}_{\mathrm{mt}}}{\mathrm{AY}_{\mathrm{t}}}$

The calculation of the average herd size is estimated by applying a linear trend and having the annual growth of average herd size $(\triangle \mathrm{ACN})$ as a scenario variable:

$$
\mathrm{ACN}_{\mathrm{t}}=\mathrm{ACN}_{1}+(\mathrm{t}-1) \triangle \mathrm{ACN}
$$

It is difficult, however, to state without doubt that the forecast for the average herd size is correct. In the 70's the growth of herds was quite stable and represented a 0.32 increase per year. By projecting this growth to 1990 the average herd size would be 10.9 cows per farm. However, in 1977 the new milk production units have been of about 24 animal unit per farm.

The number of dairy farms (MF) is obtained by dividing the number of dairy cows by the average herd size:

$$
\mathrm{MF}_{\mathrm{t}}=\frac{\mathrm{NC}_{\mathrm{t}}}{\mathrm{ACN}_{\mathrm{t}}}
$$

To exibit the functioning of the dairy structure model three production targets have been applied:

1) 110 per cent self-sufficiency in 1990

2) 120

3) 130

The average yield from dairy cows is estimated to increase by $78.6 \mathrm{~kg}$ per year, according to the linear trend from the years 1960-1978. Thus, at the end of forecast period, the average yield would be $5328 \mathrm{~kg}$ per year. At the present time the average yield from inspection herds is even higher ( $5359 \mathrm{~kg}$ in 1978), so that it is possible to achieve the estimated yield level. The yield increase is achieved by improvements in both the quality of the breed and husbandry techniques whilst the number of dairy cows is decreasing.

According to the food model the total consumption of milk products will decrease by 9 per cent in the period 1975-1990 (Table 3). If the self-sufficiency targets presented above are considered then there would be $488000-577000$ dairy cows in 1990. The number of dairy farms would then drop to $45000-53000$. The distribution of dairy farms depends on the development of average herd size and, according to the model, the share of herds of 1-4 cows would drop to 18 per cent the share of 5-10 cow herds would remain at 38 per cent and the share of larger units would grow a little: 31 per cent would be herds of 10-19 cows, 8 per cent would be herds of 20-29 cows and approximately 5 per cent of larger units.

The total consumption of beef is forecast to be 131 million $\mathrm{kg}$ in 1990 . If the average slaughter weight is $200 \mathrm{~kg}$, beef production based on dairy cows could be roughly estimated at 90-104 million $\mathrm{kg}$. This would mean an under supply of 3040 million $\mathrm{kg}$, which could be filled by the expansion of the beef breed sector, since otherwise, imports would necessarily be rather high. 
Table 3. The structural change of dairy sector in the period 1975-1990.

\begin{tabular}{|c|c|c|c|c|c|c|c|}
\hline & \multicolumn{2}{|c|}{$\begin{array}{l}\text { The consumption } \\
\text { of milk products }\end{array}$} & \multicolumn{3}{|c|}{$\begin{array}{l}\text { Milk produc tion, mill. } \mathrm{kg} \\
\text { self-sufficiency target }\end{array}$} & \multirow{2}{*}{$\begin{array}{l}\text { Average } \\
\text { yield } \\
\mathrm{kg} / \text { cow }\end{array}$} & \multirow{2}{*}{$\begin{array}{l}\text { Herd size } \\
\text { cows/farn }\end{array}$} \\
\hline & $\mathrm{kg} /$ cap & mill. $\mathrm{kg}$ & $110 \%$ & $120 \%$ & $130 \%$ & & \\
\hline 1975 & 552 & 2600 & 3172 & 3172 & 3172 & 4149 & 6.1 \\
\hline 1978 & 536 & 2540 & 3038 & 3089 & 3140 & 4385 & 7.0 \\
\hline 1981 & 522 & 2487 & 2914 & 3014 & 3113 & 4621 & 8.0 \\
\hline 1984 & 509 & 2439 & 2800 & 2947 & 3093 & 4856 & 8.9 \\
\hline 1987 & 497 & 2399 & 2696 & 2888 & 3080 & 5092 & 9.9 \\
\hline \multirow[t]{3}{*}{1990} & 487 & 2364 & 2601 & 2837 & 3074 & 5328 & 10.9 \\
\hline & \multicolumn{3}{|c|}{$\begin{array}{l}\text { Number of cows (1000) } \\
\text { self-sufficiency target }\end{array}$} & & \multicolumn{3}{|c|}{$\begin{array}{l}\text { Dairy farms (1000) } \\
\text { self-sufficiency target }\end{array}$} \\
\hline & $110 \%$ & $120 \%$ & $130 \%$ & & $110 \%$ & $120 \%$ & $130 \%$ \\
\hline 1975 & 764.5 & 764.5 & 764.5 & & 126.4 & 126.4 & 126.4 \\
\hline 1978 & 692.8 & 704.4 & 716.0 & & 98.8 & 100.5 & 102.1 \\
\hline 1981 & 630.7 & 652.2 & 673.8 & & 89.1 & 81.8 & 84.5 \\
\hline 1984 & 576.6 & 606.8 & 636.9 & & 64.6 & 67.9 & 71.3 \\
\hline 1987 & 529.4 & 567.1 & 604.8 & & 53.5 & 57.3 & 61.2 \\
\hline 1990 & 488.1 & 532.5 & 576.9 & & 45.0 & 49.1 & 53.2 \\
\hline
\end{tabular}

\subsubsection{Pork production}

The structural model for pork production is built without distinction between different lines of production.

Pork production levels are obtained from the production model. The number of pigs (NP) required to maintain a specified production level $\left(Q_{p}\right)$ is derived by applying a coefficient $k$. The annual change of this coefficient $(\triangle k)$ is a scenario parameter which depicts the change effected by breeding patterns:

(3.11) $\mathrm{k}_{\mathrm{t}}=\frac{\mathrm{NP}_{\mathrm{t}}}{\mathrm{Q}_{\mathrm{pt}}}$

(3.12) $\mathrm{NP}_{\mathrm{t}}=\left(\mathrm{k}_{1}+(\mathrm{t}-1) \triangle \mathrm{k}\right) \mathrm{Q}_{\mathrm{pt}}$

The calculation of the average piggery size is estimated by a trend line where the annual change $(\triangle \mathrm{ASP})$ is a scenario variable:

$$
\mathrm{ASP}_{\mathrm{t}}=\mathrm{ASP}_{1}+(\mathrm{t}-1) \triangle \mathrm{ASP}
$$

The number of pig farms (PF) is obtained by dividing the number of pigs by the average piggery size:

$$
\mathrm{PF}_{\mathrm{t}}=\frac{\mathrm{NP}_{\mathrm{t}}}{\mathrm{ASP}_{\mathrm{t}}}
$$

The structure of pork production can be forecast with three alternative production targets, and adjustment to the production level occurs linearly within the periods, thus:

1) 100 per cent self-sufficiency in 1990

2) 110

3) 120 


\begin{tabular}{|c|c|c|c|c|c|c|}
\hline & \multicolumn{2}{|c|}{ The consumption of pork } & \multicolumn{3}{|c|}{$\begin{array}{l}\text { Pork production, mill. kg } \\
\text { self-sufficiency target }\end{array}$} & \multirow{2}{*}{$\begin{array}{r}\text { Average } \\
\text { piggery } \\
\text { size }\end{array}$} \\
\hline & $\mathrm{kg} / \mathrm{cap}$ & mill. $\mathrm{kg}$ & $100 \%$ & $110 \%$ & $120 \%$ & \\
\hline 1975 & 26.3 & 124.0 & 124.0 & 124.0 & 124.0 & 54 \\
\hline 1978 & 28.3 & 134.0 & 134.0 & 136.7 & 139.4 & 73 \\
\hline 1981 & 30.4 & 144.8 & 144.8 & 150.6 & 156.4 & 91 \\
\hline 1984 & 32.6 & 156.6 & 156.6 & 165.9 & 175.3 & 110 \\
\hline 1987 & 35.1 & 169.2 & 169.2 & 182.7 & 196.3 & 129 \\
\hline \multirow[t]{3}{*}{1990} & 37.7 & 182.9 & 182.9 & 201.2 & 219.5 & 147 \\
\hline & \multicolumn{3}{|c|}{$\begin{array}{l}\text { Number of pigs }(1000) \\
\text { self-sufficiency target }\end{array}$} & \multicolumn{3}{|c|}{$\begin{array}{l}\text { Pig farms }(1000) \\
\text { self-sufficiency target }\end{array}$} \\
\hline & $100 \%$ & $110 \%$ & $120 \%$ & $100 \%$ & $110 \%$ & $120 \%$ \\
\hline 1975 & 1015.5 & 1015.5 & 1015.5 & 18.8 & 18.8 & 18.8 \\
\hline 1978 & 1081.5 & 1103.1 & 1124.8 & 14.9 & 15.2 & 15.5 \\
\hline 1981 & 1151.5 & 1197.6 & 1243.6 & 12.6 & 13.1 & 13.6 \\
\hline 1984 & 1225.8 & 1299.3 & 1372.9 & 11.2 & 11.8 & 12.5 \\
\hline 1987 & 1304.6 & 1408.9 & 1513.3 & 10.2 & 11.0 & 11.8 \\
\hline 1990 & 1388.0 & 1526.8 & 1665.6 & 9.4 & 10.4 & 11.3 \\
\hline
\end{tabular}

The first difficulty in applying the model is to estimate the coefficient $\mathbf{k}$ which, in the past has varied significantly. It should fall a little because of the breeding and artificial insemination. In the 70 's the coefficient $k$ has fallen very rapidly, however, it is assumed that this decrease will be smaller in the future.

There are no annual statistics available for the calculation of the average size of piggeries, so a trend forecast is built, based on the statistics from years 1969, 1974 and 1977. If the development is the same in the future then the average size will be 147 pigs per piggery in 1990 .

Pork consumption is forecast to increase by about 50 per cent by 1990 (Table 4) representing 1.4 million pigs in production. If the average size of piggeries is increasing, according to the forecasted trend the number of piggeries would fall to 9400 . With a production target of 20 per cent above the domestic consumption 1.7 million pigs will be required and 11300 piggeries in 1990.

\subsubsection{Egg production}

The structural model for egg production is analogous to the dairy model. Again, production is obtained from the production model and to calculate the number of hens a trend forecast is built for production per hen. The annual growth of egg production per hen $(\triangle \mathrm{AH})$ is a scenario parameter which can be changed:

$$
\mathrm{AH}_{\mathrm{t}}=\mathrm{AH}_{1}+(\mathrm{t}-1) \triangle \mathrm{AH}, \quad \mathrm{t}=\text { time variable }
$$

The number of hens $(\mathrm{NH})$ is obtained by dividing production $\left(\mathrm{Q}_{e}\right)$ by average production per hen:

$$
\mathrm{NH}_{\mathrm{t}}=\frac{\mathrm{Q}_{\mathrm{et}}}{\mathrm{AH}_{\mathrm{t}}}
$$


Table 5. The structural change of egg production in the period 1975-1990.

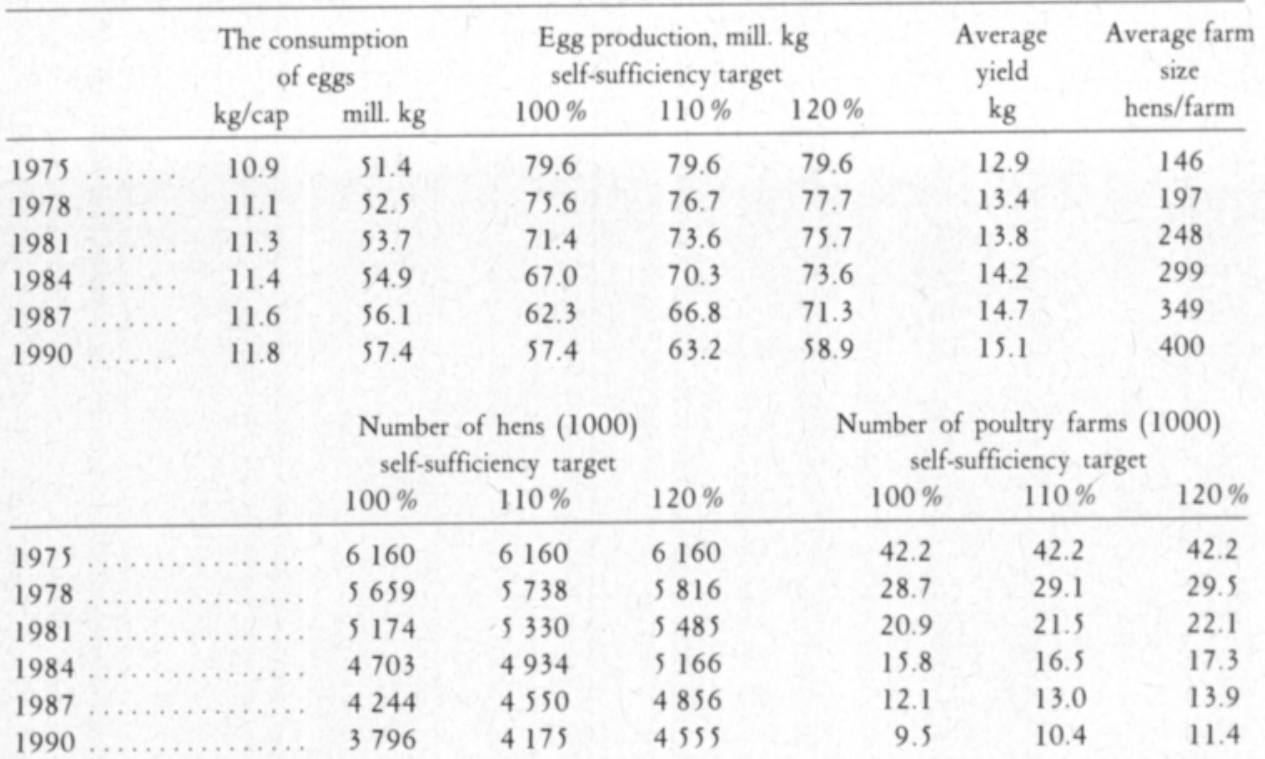

The average development of farm size (ASH) is forecast by a trend variable where the annual growth $(\triangle \mathrm{ASH})$ is a scenario variable:

$$
\mathrm{ASH}_{\mathrm{t}}=\mathrm{ASH}_{1}+(\mathrm{t}-1) \triangle \mathrm{ASH}
$$

The number of farms (HF) is obtained by dividing the number of hens by the average farm size:

$$
\mathrm{HF}_{\mathrm{t}}=\frac{\mathrm{NH}_{\mathrm{t}}}{\mathrm{ASH}_{\mathrm{t}}}
$$

The average yield per hen is forecast to grow by $0.147 \mathrm{~kg}$ per year according to previous trends (Table 5). At the end of the forecast period the production per hen would then be $15.1 \mathrm{~kg}$. The growth of the average size of farms is assumed to continue as in the past, meaning that the average size would be 400 hens in 1990 and there would be 9500-11 400 farms in 1990. The size distribution shows that egg production is still practiced on small farms: 40 per cent of farms having less than 50 hens and about 7 per cent of farms with 1000 hens.

\subsubsection{Non-animal farms}

In case of non-animal farms the structure of the model cannot be built beginning from the production targets since a part of plant production comes from animal farms. Also, statistics from non-animal farms have been collected only from the 1974 and 1977 farm registers. 
The rapid growth of non-animal farms which occured in the period 1974-77 cannot continue if we consider the existing trend towards a reduction in the number of farms. Therefore, in order to avoid an unrealistic value for non-animal farms in the model a hyperbole function has been applied (Fig. 1):

$$
\begin{aligned}
& \text { NAF }_{\mathrm{t}}=0.8 \text { FARMS }-\frac{\mathrm{a}}{\mathrm{t}+\mathrm{b}} \\
& \text { where } \mathrm{NAF}=\text { non-animal farms } \\
& \begin{array}{ll}
\mathrm{FARMS} & =\text { all farms } \\
\mathrm{a}, \mathrm{b} & =\text { constants } \\
\mathrm{t} & =\text { time variable }
\end{array}
\end{aligned}
$$

There is a maximum share of 80 per cent for non-animal farms which is rather high. However, this limit has been selected since the forecast for 1990 is 55 per cent, which seems quite possible.

Calculation of the average acreage of all non-animal farms has been estimated by a trend function based on the years 1974-77. The growth is predicted to be 0.15 ha per year and the average size 9.8 ha per farm in 1990 . There would be 81900 non-animal farms with 804000 hectares of land in 1990.

Since in the model non-animal farms are completely separated from animal farms a control factor $\mathrm{r}$ calculated:

$$
\begin{aligned}
& r=\frac{\text { FARMS }_{\mathrm{t}}-\mathrm{NAF}_{\mathrm{t}}}{M \mathrm{~F}_{\mathrm{t}}+\mathrm{PF}_{\mathrm{t}}+\mathrm{HF} \mathrm{F}_{\mathrm{t}}} \quad \times 100 \\
& \text { where FARMS = number of farms } \\
& \text { NAF }=\text { non-animal farms } \\
& \text { MF = dairy farms } \\
& \mathrm{PF} \quad=\text { pig farms } \\
& \mathrm{HF} \quad=\text { poultry farms } \\
& \mathrm{t}=\text { time variable }
\end{aligned}
$$

Fig. 1. The number of all farms and non-animal farms.

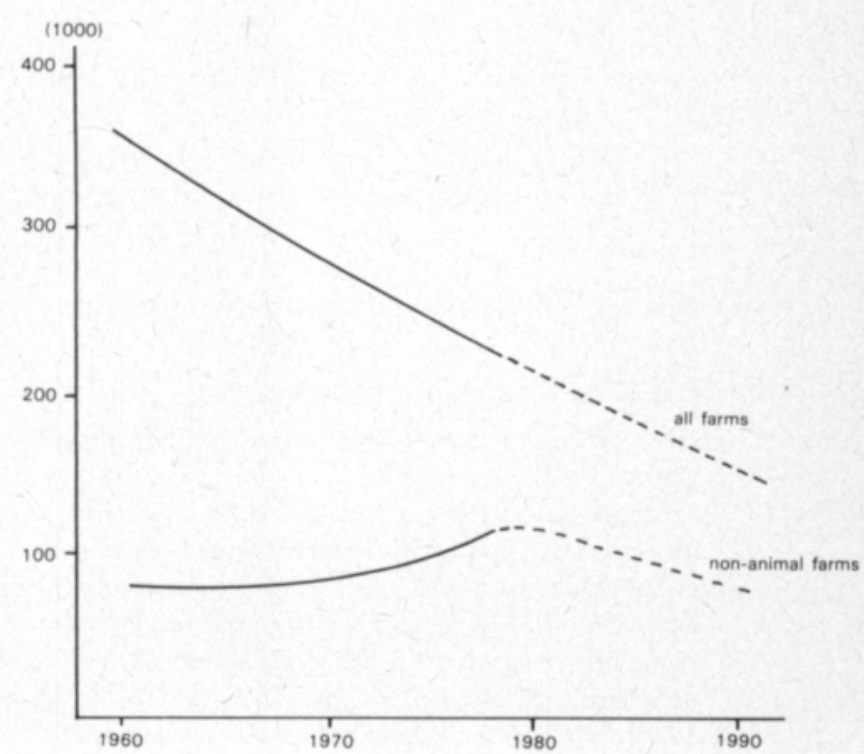


Table 6. Non-animal farms in the period 1975-1990.

\begin{tabular}{lcccc}
\hline & $\begin{array}{c}\text { Number of } \\
\text { farms }\end{array}$ & $\begin{array}{c}\text { Per cent } \\
\text { of all farms }\end{array}$ & $\begin{array}{c}\text { Acreage } \\
(1000 \mathrm{ha})\end{array}$ & $\begin{array}{c}\text { Average farm } \\
\text { size }\end{array}$ \\
\hline $1975 \ldots \ldots \ldots \ldots$ & 109.4 & 40 & 828.4 & 7.6 \\
$1978 \ldots \ldots \ldots \ldots \ldots$ & 116.5 & 48 & 934.2 & 8.0 \\
$1981 \ldots \ldots \ldots \ldots$ & 111.7 & 52 & 945.9 & 8.5 \\
$1984 \ldots \ldots \ldots \ldots$ & 102.6 & 54 & 915.2 & 8.9 \\
$1987 \ldots \ldots \ldots \ldots$ & 92.2 & 55 & 863.9 & 9.4 \\
$1990 \ldots \ldots \ldots \ldots$ & 81.9 & 55 & 850.0 & 9.8 \\
\hline
\end{tabular}

If this factor is larger than one hundred per cent then the forecast is not logical and parameters have to be adjusted accordingly. The parameters for the model are logical, however, since the value of $\mathrm{r}$ for 1990 is approximately 95 per cent.

Acknowledgements. This article is a part of the Finnish food model project which has been financed by the Ministry of Agriculture and Forestry. The assistance of the staff of the Agricultural Economics Research Institute is also greatly appreciated.

\section{References}

HASSINEN, S. 1980. Maatalouden tuotantorakenteen kehitys. Maatal. tal tutk.lait. Tied. No 66. 91 p. KETTUNEN, L. 1980. Food and agriculture model for Finland. J. Scient. Agric. Soc. Finl. 52: 441-455 ROUHIAINEN, J. 1979. Changes in demand for food items in Finland 1950-1977 with consumption forecasts for 1980, 1985 and 1990. Maatal tal. tutk.lait. Julk. 40. 84 p.

WALLENBECK, A. 1979. Framskrivningar av strukturen i lantbruket vilka bygger på en metod med transformerade frekvensfunktioner. Framskrivning av structurutvecklingen för jordbruket. Lantbr.ekon. Samarb.nämnd. Ration.grupp. p. 155-243.

Ms received September 10, 1980.

\section{SELOSTUS}

\section{Maatalouden rakennekehityksen simulointimalli}

\section{Seppo Hassinen ja Lauri Kettunen \\ Maatalouden taloudellinen tutkimuslaitos, Rukkila, 00001 Helsinki 100}

Maatalouden taloudellisessa tutkimuslaitoksessa on kehitetty laajaa maataloussektorin suunnittelumallia, ns. Suomen ravintotuotantomallia. Tutkimusprojektin tavoitteena on laatia matemaattinen mallisto, jonka avulla voidaan ennustaa maatalouden kehitystä annettujen lähtötietojen perusteella. Mallistolla toivotaan pystyttãvän selvittảmãăn mm. miten maataloustuotantomme omavaraisuus voidaan säilyttää kaikissa oloissa.

Ravintomallin yhden osan muodostaa maatalouden rakennekehityksen simulointimalli. Maatalouden rakennetta kuvataan maatalousväestön määrällä sekä kaikkien tilojen, lypsykarjatilojen, sikatilojen, kanatilojen ja kotieläimettömien tilojen lukumäärällä, keskikoolla ja kokojakaumalla. 
Maatalousvãestō lasketaan ennustamalla sen prosenttiosuus BKT:n funktiona. Tilojen lukumããrä saadaan maatalousvãestön mãärästã olettamalla perheen koko vakioksi. Tilojen keskipeltoala saadaan jakamalla kokonaispeltoala tilojen lukumäärällä. Tilojen jakautumisen eri tilasuuruusluokkiin katsotaan noudattavan approksimoiden logaritmisesti normaalista jakautumaa. Rakennemallin tuottaman perusskenaarion mukaan maatiloja olisi vuonna $1990148000 \mathrm{kpl}$ keskipeltoalan kohotessa 17 hehtaariin.

Tuotantorakennemallin lähtökohtana on tuotantomäärät, jotka saadaan kulutusennusteista ja omavaraisuustavoitteista. Kotieläinten keskituotoksien kehityksestä on tehty trendiennusteet. Kotieläintilojen keskikokojen kehitystä ennustetaan samoin trendisuorien avulla. Tähän menettelyyn liittyvät tuotantorakennemallin ehkä vakavimmat puutteet, koska mm. eri tuotantotavoitevaihtoehtojen vaikutusta tilojen keskikokojen kehitykseen ei ole pystytty arvioimaan. Ennustejakson lopussa olisi perusskenaarioiden mukaan 45 000-54 000 lypsykarjatilaa keskikarjakoon ollessa 11 lehmää. Sikatilojen lukumääräksi malli tulostaa 9 400-11 300 ja kanatilojen lukumääräksi 9 500-11 400. Kotieläimettömiä tiloja olisi mallin mukaan 81900 vuonna 1990 mikä merkitsce 55 \%:n osuutta ennustetusta maatilojen yhteismäärästã.

\section{APPENDIX}

VARIABLES

$\mathrm{ACN}=$ the average herd size

$\triangle \mathrm{ACN}=$ the annual change of average herd size

$\mathrm{AH}=$ the egg yield per hen

$\triangle A H=$ the annual change of average egg yield

ASF $^{\prime}=$ the average farm size

ASH = the average poultry farm size

$\triangle A S H=$ the annual change of average poultry farm size

ASP $=$ the average piggery size

$\triangle A S P=$ the annual change of average piggery size

$\mathrm{AW}=$ the agricultural population

AW $(\%)=$ the share of the agricultural population

AY $=$ the milk yield per cow

$\triangle A Y=$ the annual change of average milk yield

FARMS $=$ the number of farms

GDP = Gross Domestic Product

MF = the number of dairy farms

NAF $=$ the number of non-animal farms

$\mathrm{NC} \quad=$ the number of dairy cows

$\mathrm{NH} \quad=$ the number of hens

$\mathrm{NP} \quad=$ the number of pigs

PF $\quad=$ the number of pig farms

$\mathrm{Qe} \quad=\mathrm{egg}$ production

$\mathrm{Qm} \quad=$ milk production

Qp $\quad=$ pork production

$\mathrm{t}=$ time variable

TAREA $=$ the total acreage

$\mathrm{W}=$ population 